\title{
The Barriers and Facilitators of the Degree of Digital Use in the Travel Services Supply Chain: The Moderating Role of Firm Size
}

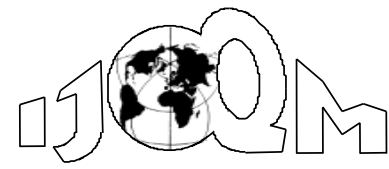

Volume 25, Number 4

December 2019, pp. 253-274

\author{
Deviprasad Ghosh \\ Satyabhusan Dash \\ Indian Institute of Management, Lucknow \\ (efpm04018@iiml.ac.in) \\ (satya@iiml.ac.in)
}

This study identified the barriers and facilitators of the degree of digital use in the travel services supply chain from the perspective of retail travel agencies and online travel suppliers. While past studies have established the direct effects of firm size, this study on Micro, Small and Medium Enterprises (MSMEs) asserts that firm size is a contingency variable and conceptualizes its impact on the influence of the barriers and facilitators of digital usage. The study defined a process-based conceptualization of Digital Usage. This paper uses a multi-theoretical perspective to develop a theoretical framework, research propositions, and conceptual model. The study contributed to the domain of MSMEs, B2B digital usage, distinct from digital adoption.

Keywords: B2B Digital Usage, Supplier-Intermediary Relationship, Travel Services Supply Chain, Online Travel Supplier, Retail Travel Agency, MSMEs India

\section{Introduction}

Digital technology disrupts the travel services supply chain. The study has pointed out that digital technology is redefining the relationship between travel suppliers and retail travel agencies. The advent of digital technologies is redefining the relative competitive advantages of travel retailers and travel suppliers in the marketplace. Retail travel agencies are facing disintermediation, with travel suppliers targeting customers directly online and increased competition from new online travel agencies (OTAs). Retail travel agencies are developing a re-intermediation strategy by building direct relationships with online travel suppliers through alliances and partnerships (Buhalis and Licata, 2002).

Travel and tourism services are essential in the service industry in India, with a size of US\$ 71.70 billion (2016). Travel and tourism services contributed $9.6 \%$ to GDP in Jan.-Dec. 2016. The industry size is expected to reach US\$ 488 billion by 2029 (CAGR 6.7\%) (IBEF Report 2017). Travel services are the first adopters of digital commerce in India. Online travel accounts for the largest share (61\% share) of the digital commerce market in India (IAMAI-IMRB Report, 2016).Digital travel sales contribute $41 \%$ of total travel sales and are growing by CAGR $17.8 \%$. (Indian Online Travel Industry Report 2015, Aranca Consulting) (Table 1). 
Table 1 Digital Travel Sales in India, by Travel Category, December 2016

\begin{tabular}{|c|c|c|}
\hline Travel Category & $\begin{array}{c}\text { Digital Travel Sales (US\$ } \\
\text { Billion) }\end{array}$ & $\begin{array}{c}\text { \% Share of the Total Digital } \\
\text { Sales }\end{array}$ \\
\hline Air Ticket Booking & 8.1 & $60 \%$ \\
\hline $\begin{array}{l}\text { Railway Ticket } \\
\text { Booking }\end{array}$ & 3.6 & $26 \%$ \\
\hline Hotel Booking & 1.2 & $9 \%$ \\
\hline Bus Ticket Booking & 0.3 & $3 \%$ \\
\hline Car/ Cab Hire & 0.2 & $1 \%$ \\
\hline Tour Packages & 0.1 & $1 \%$ \\
\hline Travel Insurance & 0.1 & $1 \%$ \\
\hline Total Digital Sales & 13.6 & $100 \%$ \\
\hline
\end{tabular}

The B2B segment (corporations \& SMEs) accounts for $49 \%$ of the total travel sales. However, the share of B2B digital travel sales is meager (Praxis report, Livemint, 2018). Travel agencies (OTAs/RTAs) contribute 63\% ( $\$ 5.7$ billion) of total digital sales and balance $37 \%$ by direct travel suppliers (Praxis report, Livemint, 2018). Three large online travel agencies (OTAs)-MakeMyTrip.com (48\%), Yatra.com (24\%) and Cleartrip.com (18\%)-dominate digital travel sales. Approximately $7 \%$ of digital transactions are accounted for by retail travel agencies (mostly MSMEs) and smaller OTAs (Red Seer Consulting report, 2010).IRCTC provides $14 \%$ of $37 \%$ of direct travel supplier services for rail travel booking alone. Industry data suggest that large online travel agencies dominate digital sales. Most of the retail travel agencies that are MSMEs (90\%) have lower digital sales.

Thus, the identification of the barriers and facilitators of the degree of digital use and the buyer firm size as a factor influencing B2B digital travel services in the relationship between retail travel agencies and online travel suppliers need to be investigated.

\section{Research Objectives}

At the aggregate level, the research in the domain of digital adoption and usage has been more focused on understanding digital adoption behavior, and few studies have focused on understanding digital usage behavior (Andreu et al., 2010). Furthermore, there are very few studies on digital usage in the B2B services context, particularly in the case of supplier-intermediary relationships (Thao \& Swierczek, 2008; Shouk et al. 2012).

In the literature, very few studies have categorized the antecedent factors of digital usage into barriers and facilitators in a travel services context (Heung, 2003; Law, Leung, \& Wong, 2004; Tsai, Huang, \& Lin, 2005, Thao \& Swierczek, 2008; Shouk 
et al. 2012). There have been almost negligible studies on B2B travel services (Thao \& Swierczek, 2008; Shouk et al. 2012).

There has been minimal above mentioned exploration on the effects of firm size on digital usage in a B2B context (Wu et al., 2003; Zhu and Kraemer 2005; Wu et al., 2007; Bigne et al., 2008; Ghobakhloo et al., 2011; Ramdani et al., 2013; Sila, 2013; Rahayu \& Day, 2015; Brown \& Kaewkitipong, 2009) and negligible studies on B2B travel services (Bigne et al., 2008; Brown \& Kaewkitipong, 2009).

Past literature has conceptualized digital adaptation and usage as an innovation adoption in organizations (Jackson \& Harris, 2003; Patterson, Grimm, \& Corsi, 2003); therefore, digital usages outcomes are treated as a unitary construct variable (Wu et al. 2003). Exceptionally few studies have conceptualized digital usage as a process-based approach in value chain activities such as the supplier interface (supplier communication, supplier transaction), customer interface (customer communication, customer transaction), and the impact of external relationships with suppliers or customers on digital usage (Wu et al., 2007; Wu et al., 2003, Andreu et al., 2010, Bigne et al., 2008). The study conceptualizes digital usage as a degree of digital use. The degree of digital use explains the extent of the use of digital systems and processes to conduct value chain activities in the supplier interface.

Based on the research gaps and problems, the objective of the study is twofold:

1. To identify the determinant factors that are barriers and facilitators of the degree of digital use in the relationship between online travel suppliers and retail travel agencies.

2. To understand the role of firm size in the influence of these barriers and facilitators of the degree of digital use in the relationship between online travel suppliers and retail travel agencies.

\section{Method}

\section{Methodology}

The paper used the concept of the deductive method of theory development. The study involved a literature review and travel services industry digital usage data analysis and online secondary research of retail travel agencies in understanding the current situation in travel services supply-chain.

\section{Sampling Procedure}

A literature review of empirical research papers was carried out for the identification of determinant factors as antecedents of B2B Digital Usages in travel services. Online academic databases sources such as Google Scholar, EBSCO, ProQuest, Scopus, and journal publishers' databases using query keywords and phrases "Barriers and Facilitators of B2B Digital Usages" for "B2B Travel Services" "MSMEs/SMEs" identified the relevant literature for the study. The literature was selected basis keywords in the paper title, abstracts, and keywords section in academic literature year 2000 onwards given that our study focus is usages postadoption. Based on the negative or positive impact of the determinant factors on digital usages, it was categorized as barriers or facilitators, respectively. The identified determinant factors in B2B travel services that appeared in similar studies in other B2B Digital Usages contexts were also selected to understand the constructs, definitions, and operationalization. A separate literature search conducted in diverse 
domains helped to choose the original seminal papers in theory development that contributed to the development of the proposed framework.

Secondary qualitative research helped us to understand the current digital usages in retail travel agencies' supply-chain in the Indian context. The online activities of thirty retail travel agencies in metros and mini-metros in the country were investigated in terms of their websites, social media pages, online directories, and digital media practices. Retail Travel Agencies in India are largely MSMEs $(90 \%$ of Firms), and $95 \%$ of Firms have less than 250 employees. 56\% of retail travel agencies out of a total of about 24,000 travel agencies are in the top eight cities of the country. (As per fundoodata.com web portal, Sunrise Consultancy Services, February 2020). Moreover, our study is for digital usages; therefore, our research in metros and mini-metros (Top eight cities) is relevant since top cities have achieved higher levels of digital adoption. We, therefore, limit our sample for an online secondary study of MSME Retail Travel Agencies to the top eight cities in the country. The thirty sampling units were selected based on convenience sampling from the available database on fundoodata.com web portal with the representation of micro, small, and medium enterprises basis population proportion. The firms were classified as per the MSMEs definition in India (2006). However, the size of travel agencies based on the number of full-time employees was kept within 250, to adhere to international classifications of SMEs. (Table 2).

Table 2 MSME Retail Travel Agency Profile

\begin{tabular}{|l|l|c|}
\hline \multicolumn{1}{|c|}{ Category } & \multicolumn{1}{c|}{$\begin{array}{c}\text { Investment in Equipment as per MSME Definition } \\
\text { in India (2006) }\end{array}$} & $\begin{array}{c}\text { No. of Travel } \\
\text { Agency }\end{array}$ \\
\hline $\begin{array}{l}\text { Micro- } \\
\text { Enterprise }\end{array}$ & Less than 10 Lacs & 6 \\
\hline Small Enterprise & 10 Lacs to less than 2 Crores & 12 \\
\hline $\begin{array}{l}\text { Medium } \\
\text { Enterprise }\end{array}$ & 2 Crores to less than 5 Crores & 12 \\
\hline & TOTAL & $\mathbf{3 0}$ \\
\hline
\end{tabular}

\section{Proposed Theoretical Framework}

Most of the study in the domain adopted theories such as Tornatzky and Fleischer's (1990) Technology, Organization and Environment (TOE) framework, Rogers' Diffusion of Innovations (DOI) theory, the Institutional Theory (IT) (DiMaggio and Power, 1983) and the Iacovou et al. Model (1995) that explains inter-organizational systems (IOSs). The studies concentrated on the Information Technology aspect of the context. There is a limited exploration of inter-organizational theories with a behavioral perspective. This study uses multiple theoretical perspectives from the diverse domains of information technology, consumer behavior, relationship marketing, and B2B marketing to develop the proposed framework. The proposed theoretical framework, with a brief explanation of the theories applied with its application for the study context presented in Figure 1. 


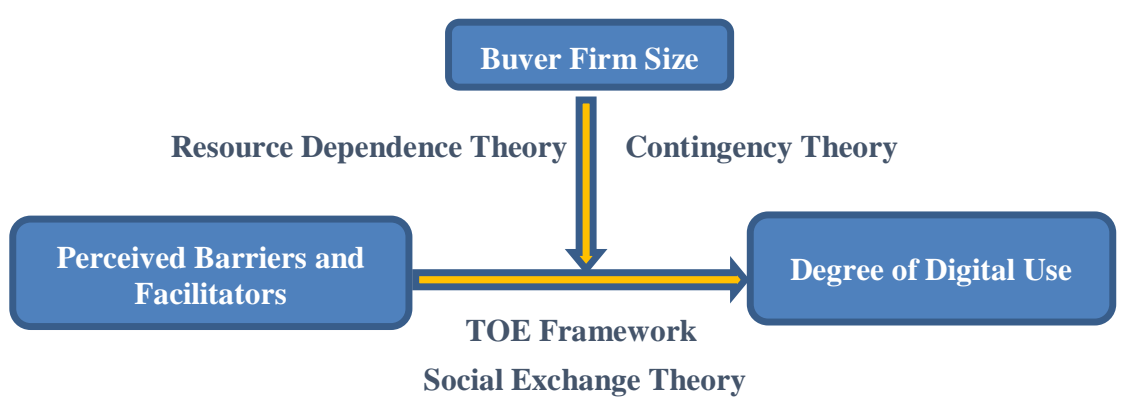

Figure 1 Proposed Theoretical Framework

Technological, Organizational, and Environmental (TOE) Framework (Tornatzky, Fleischer \& Chakrabarti, 1990): The theory identified three broad contexts, i.e., technological, organizational, and environmental contexts, which have an impact on IT innovation-related decisions and the usage of technological innovations in organizations. The TOE framework is the most widely used theory in empirical research in digital adoption and usage. However, the criticism of the method is that it explains innovation adoption for large organizations, but not for SMEs.The framework does not cover the individual (managerial) factor, i.e., the influence of the owner-manager in technology adoption and usage decisions (Ghobakhloo and Tang, 2013). The model also does not include context-specific factors such as inter-organizational factors relevant for B2B digital usage (Sila, 2013). We, therefore, modified the technological, organizational, and environmental (TOE) framework with the addition of contextual factors inter-organizational factors and individual (managerial) factors for perceived barriers and facilitators impacting B2B digital usage, positively or negatively.

Social Exchange Theory (SET) (George Homans, 1958; Blau, 1964 and Emerson, 1976): This theory involves the evaluations of outcomes and motivation to comply with cost-benefit analysis while forming relationships. The theory proposes that the relationships one chooses to develop and maintain are the ones that maximize our benefits and minimize our costs. We feel positive or negative toward a relationship on the basis of three factors - cost-benefit analysis, comparison level, and comparison level alternatives. In the study, the outcome of perceived facilitators (relationship benefits) will have a positive impact on the degree of digital use, and perceived barriers (relationship cost) will have a negative impact on the degree of digital use, based on comparisons with existing practices in the relationship between retail travel agencies and travel suppliers. While the TOE framework explains the determinant factors as an influence on the degree of digital use, social exchange theory explains the basis for a positive or negative impact on the relationship.

Resource Dependence Theory (RDT) (Pfeffer \& Salancik, 2003): According to resource dependence theory, organizations try to control the resources that are critical to them through the management of factors in the environment. Organizations either employ control (power) mechanisms or work toward 
coordination and cooperation in relationships with other organizations to reduce environmental uncertainty. Uncertainty may arise due to market unpredictability, other organizations' control over critical resources, or the scarcity of essential resources. In the relationship between retail travel agencies and online travel suppliers, retail travel agencies lack internal resources to invest in IT in terms of human resources and financial resources. The agency, therefore, pursues the needed resources from supply-chain partners such as online travel suppliers and technology vendors to access and implement digital travel systems. Smaller travel agencies will have fewer resources compared to larger agencies and, therefore, more dependence on external partners to manage environmental uncertainties and business risk. Thus, the influence of barriers and facilitators on the degree of digital use in B2B travel services is contingent on buyer firm size. Very few studies have taken a contingency view of the determinant factor of buyer firm size on B2B digital usage (Sila 2013).

Contingency Theory (CT) (Blanton, Watson \& Moody, 1992): Contingency theory defines contingency variables. Contingent variables are those that moderate the effects of organizational characteristics on organizational performance or outcomes. The theory states that organizations are seeking to design their organizational attributes in a manner that can handle uncertainties arising out of contingencies and deliver results even when there is a change in contingencies. Contingency theory explains buyer firm size as a contingent variable, where the size of the firm is considered a proxy for organizational ability and resources to influence the outcome (digital usages). The review uses both Indian and international classifications - (a) number of employees and (b)investment in equipment- to categorize buyer firm size for the generalization of the concept.

\section{Review Findings and Discussions}

\subsection{Identification of Barriers and Facilitators of the Degree of Digital Use}

A literature review of empirical research papers was undertaken to investigate the determinant factors as antecedents of B2B travel services. The determinant factors identified were also investigated in other B2B digital usage contexts in the literature for a better understanding of their factors and definitions. The study revealed that a determinant factor could be a barrier or facilitator, depending on the context of the study. The identified antecedent factors that have a positive impact on digital usage were categorized as facilitators, and those having a negative impact on digital usage were classified as barriers. The context of the study is the relationship between retail travel agencies and online travel suppliers in B2B travel services. The determinant factors are categorized into perceived barriers (Table 3) and perceived facilitators (Table 4) based on relevant literature outcomes.

Based on the literature review, the paper categorized seven barriers and thirteen facilitators of B2B digital usage as technological factors, environmental factors, inter-organizational factors, organizational factors, and individual (managerial) factors in the relationship between retail travel agencies and online travel suppliers. The determinant factors, such as organizational factors and individual (managerial) factors, are by nature, intrinsic factors, and categorized as internal factors. Technological, environmental, and inter-organizational factors are extrinsic factors and categorized as external factors (Table 5). 
Table 3 Perceived Barriers of B2B Digital Usages in Travel Services

\begin{tabular}{|c|c|c|c|}
\hline $\begin{array}{c}\text { Perceived } \\
\text { Barriers }\end{array}$ & Operational Definition (Source) & $\begin{array}{l}\text { Type of } \\
\text { Factors }\end{array}$ & Relevant Literature \\
\hline $\begin{array}{l}\text { IT Infrastructure } \\
\text { Problems }\end{array}$ & $\begin{array}{l}\text { Lack of public infrastructure readiness in terms of } \\
\text { Internet access, available, and fast Internet } \\
\text { connections. (Thao and Swierczek, 2008) }\end{array}$ & $\begin{array}{l}\text { Technological } \\
\text { Factors }\end{array}$ & $\begin{array}{l}\text { Thao and Swierczek } \\
\text { (2008); Zhu et al. } \\
\text { (2003); Teo et al. } \\
\text { (2006a); Shouk et al. } \\
\text { (2012); }\end{array}$ \\
\hline $\begin{array}{l}\text { Perceived } \\
\text { Security Risk }\end{array}$ & $\begin{array}{l}\text { Security Risk is a threat which creates "circumstance, } \\
\text { condition, or event that can cause economic hardship } \\
\text { to data or network resources that may result in } \\
\text { destruction, disclosure, modification of data, denial of } \\
\text { service and fraud, waste, and abuse" (Thao and } \\
\text { Swierczek, 2008) }\end{array}$ & $\begin{array}{l}\text { Technological } \\
\text { Factors }\end{array}$ & $\begin{array}{l}\text { Thao and Swierczek, } \\
\text { (2008); Shouk et al. } \\
(2012) ; \text { Kaynak et al. } \\
(2005) \text {; Oliveira and } \\
\text { Martins (2008, 2009, } \\
\text { 20010b, 2011) }\end{array}$ \\
\hline $\begin{array}{l}\text { Organizational } \\
\text { IT Weakness }\end{array}$ & $\begin{array}{l}\text { Obstacles such as retailer's inability to adopt Internet } \\
\text { Technology, limited resources including finance, } \\
\text { skills, and knowledge creates a technology gap with } \\
\text { suppliers. (Thao and Swierczek, 2008) }\end{array}$ & $\begin{array}{l}\text { Organizational } \\
\text { Factors }\end{array}$ & $\begin{array}{l}\text { Thao and Swierczek, } \\
\text { 2008; Oliveira and } \\
\text { Martins }(2008,2009 \text {, } \\
\text { 20010b, 2011) }\end{array}$ \\
\hline $\begin{array}{l}\text { Lack of Critical } \\
\text { Mass (Limited } \\
\text { Number of } \\
\text { Users) }\end{array}$ & $\begin{array}{l}\text { The relatively large number of customers and } \\
\text { suppliers not being online and decreasing productivity } \\
\text { levels due to unnecessary usage. (Kaynak et al. 2005) }\end{array}$ & $\begin{array}{l}\text { Environmental } \\
\text { Factors }\end{array}$ & $\begin{array}{l}\text { Shouk et al. (2012); } \\
\text { Kaynak et al. (2005); } \\
\text { Walczuch et al., } \\
(2000)\end{array}$ \\
\hline $\begin{array}{l}\text { Legal and } \\
\text { Regulatory } \\
\text { Issues }\end{array}$ & $\begin{array}{l}\text { The lack of government regulations and legal } \\
\text { standards to deal with the intricacies of EC. (Thao and } \\
\text { Swierczek, 2008) }\end{array}$ & $\begin{array}{l}\text { Environmental } \\
\text { Factors }\end{array}$ & $\begin{array}{l}\text { Thao and Swierczek, } \\
\text { 2008; Kaynak et al. } \\
\text { (2005); Sila, (2015). }\end{array}$ \\
\hline $\begin{array}{l}\text { High } \\
\text { Technology } \\
\text { Cost }\end{array}$ & $\begin{array}{l}\text { Limited resources and IT implementation costs. The } \\
\text { four cost components are connection costs to the } \\
\text { internet, the cost of adequate hardware/software, set- } \\
\text { up cost, and maintenance costs. (Ghobakhloo et al., } \\
\text { 2011). }\end{array}$ & $\begin{array}{l}\text { Technology } \\
\text { Factors }\end{array}$ & $\begin{array}{l}\text { Shouk et al. (2012); } \\
\text { Al-Qirim (2007); } \\
\text { Ghobakhloo et al. } \\
\text { (2011); Kaynak et al. } \\
\text { (2005); Sila, (2015). }\end{array}$ \\
\hline $\begin{array}{l}\text { Perceived } \\
\text { Complexity }\end{array}$ & $\begin{array}{l}\text { Complexity is the difficulty perceived by adopters in } \\
\text { adopting innovation. It refers to the degree to which an } \\
\text { innovation is perceived relatively difficult to } \\
\text { understand and use. (Rogers, 1983) }\end{array}$ & $\begin{array}{l}\text { Technology } \\
\text { Factors }\end{array}$ & $\begin{array}{l}\text { Brown \& } \\
\text { Kaewkitipong, 2009; } \\
\text { Shouk et. al (2012); } \\
\text { Raymond, (2001); } \\
\text { Rogers (1983); Sila, } \\
\text { (2015). }\end{array}$ \\
\hline $\begin{array}{l}\text { Lack of Supplier } \\
\text { Trust }\end{array}$ & $\begin{array}{l}\text { Lack of confidence that travel suppliers and digital } \\
\text { travel systems are safe and trustworthy. (Lama et al., } \\
2020 \text { ) }\end{array}$ & \begin{tabular}{|l|} 
Inter- \\
organizational \\
Factors
\end{tabular} & Lama et al. (2020) \\
\hline
\end{tabular}

Table 4 Perceived Facilitators of B2B Digital Usages in Travel Services

\begin{tabular}{|l|l|l|l|}
\hline $\begin{array}{l}\text { Perceived } \\
\text { Facilitators }\end{array}$ & \multicolumn{1}{|c|}{ Operational Definition (Source) } & \multicolumn{1}{|c|}{$\begin{array}{c}\text { Type of } \\
\text { Factors }\end{array}$} & \multicolumn{1}{|c|}{ Relevant Literature } \\
\hline $\begin{array}{l}\text { Perceived } \\
\text { Relative } \\
\text { Advantage }\end{array}$ & $\begin{array}{l}\text { The degree to which perception of } \\
\text { innovation is that it is better than the idea } \\
\text { it supersedes. (Rogers, 1983) }\end{array}$ & $\begin{array}{l}\text { Thouk et al. (2012); Thao and Swierczek, } \\
\text { Technological } \\
\text { Factors }\end{array}$ & $\begin{array}{l}\text { (2008); Raymond, (2001); Ghobakhloo et } \\
\text { al. (2011); Rahayu \& Day, (2015); } \\
\text { Ramdani et al., (2013); Zhu et al. } \\
\text { (2006a); Kaynak et al. (2005); Sila, } \\
\text { (2015). }\end{array}$ \\
\hline
\end{tabular}




\begin{tabular}{|c|c|c|c|}
\hline $\begin{array}{l}\text { Perceived } \\
\text { Facilitators }\end{array}$ & Operational Definition (Source) & $\begin{array}{l}\text { Type of } \\
\text { Factors }\end{array}$ & Relevant Literature \\
\hline $\begin{array}{l}\text { Perceived } \\
\text { Compatibility }\end{array}$ & $\begin{array}{l}\text { The degree to which perception of } \\
\text { innovation is consistent with existing } \\
\text { values, past experiences, and needs of } \\
\text { potential adopters. (Rogers, 1983) }\end{array}$ & $\begin{array}{l}\text { Technological } \\
\text { Factors }\end{array}$ & $\begin{array}{l}\text { Shouk et. al (2012); Raymond, } \\
\text { (2001);Ghobakhloo et. al. (2011); Rahayu } \\
\text { \& Day, (2015); Ramdani et. al., (2013); } \\
\text { Zhu et al. (2006a); Kaynak et. al. (2005); } \\
\text { Sila, (2015). }\end{array}$ \\
\hline $\begin{array}{l}\text { B2B } \\
\text { Relationship } \\
\text { Intensity }\end{array}$ & $\begin{array}{l}\text { High level of interactions involves } \\
\text { greater collaboration and more } \\
\text { information exchange which positively } \\
\text { influences innovation adoption in } \\
\text { services (Bigne et al., 2008) }\end{array}$ & $\begin{array}{l}\text { Inter- } \\
\text { Organizational } \\
\text { Factors }\end{array}$ & $\begin{array}{l}\text { Bigne et al., 2008; Alam, 2002; Sila, } \\
\text { (2015). }\end{array}$ \\
\hline $\begin{array}{l}\text { Supplier } \\
\text { Pressure }\end{array}$ & $\begin{array}{l}\text { Supplier (Coercive) pressures are a set of } \\
\text { formal or informal forces exerted on } \\
\text { organizations by other organizations } \\
\text { upon which the former organizations } \\
\text { depend. (Dimaggio and Powell, 1983) }\end{array}$ & $\begin{array}{l}\text { Environmental } \\
\text { Factors }\end{array}$ & $\begin{array}{l}\text { Bigne et. al., (2008); Raymond, (2001); } \\
\text { Ghobakhloo et. al, (2011); Rahayu \& } \\
\text { Day, (2015); Sila, (2013); Sila, (2015). }\end{array}$ \\
\hline $\begin{array}{l}\text { Customer } \\
\text { Pressure }\end{array}$ & $\begin{array}{l}\text { Customers actively influence the system } \\
\text { to change according to their } \\
\text { requirements, allowing the supplier to } \\
\text { adjust the system to accommodate the } \\
\text { customer better. (Wu \& Lee, 2005) }\end{array}$ & $\begin{array}{l}\text { Environmental } \\
\text { Factors }\end{array}$ & $\begin{array}{l}\text { Bigne et al., (2008); Andreu et al., } \\
\text { (2010); Wu et al., (2003); Rahayu \& Day, } \\
\text { (2015); Ghobakhloo et al., (2011); Sila, } \\
\text { (2015). }\end{array}$ \\
\hline $\begin{array}{l}\text { Industry } \\
\text { Pressure }\end{array}$ & $\begin{array}{l}\text { An organization, when faced with a } \\
\text { problem from ambiguous causes, } \\
\text { imitates similar organizations in the } \\
\text { industry that it perceives as more } \\
\text { legitimate or successful. (Wu \& Lee, } \\
\text { 2005) }\end{array}$ & $\begin{array}{l}\text { Environmental } \\
\text { Factors }\end{array}$ & $\begin{array}{l}\text { Andreu et. al., (2010); Brown \& } \\
\text { Kaewkitipong, 2009; Wu et al., (2003); } \\
\text { Wu et. al, (2007); (Wu \& Lee, 2005); } \\
\text { Rahayu \& Day, (2015); Sila, (2013); } \\
\text { Ramdani et. al., (2013); Zhu and Kraemer } \\
\text { (2005); Zhu et al. (2003); Oliveira and } \\
\text { Martins (2008, 2009, 20010b, 2011); Teo } \\
\text { et al. (2006); Zhu et al. (2006a); Sila, } \\
\text { (2015). }\end{array}$ \\
\hline $\begin{array}{l}\text { Environment } \\
\text { Uncertainty }\end{array}$ & $\begin{array}{l}\text { Environment Uncertainty (Turbulence) } \\
\text { refers to the frequent and unpredictable } \\
\text { market and technical changes in the } \\
\text { industry. Market uncertainty relates to } \\
\text { the changes in customer preferences, and } \\
\text { technologicalrisk relates to the changes } \\
\text { in the technology in the external } \\
\text { environment. } \\
\text { (Jaworski and Kohli, 1993). }\end{array}$ & $\begin{array}{l}\text { Environmental } \\
\text { Factors }\end{array}$ & $\begin{array}{l}\text { Huang (2006); Shouk et al. 2012; Brown } \\
\text { \& Kaewkitipong, 2009; Jaworski and } \\
\text { Kohli, 1993; Raymond, (2001); Sila, } \\
\text { (2015). }\end{array}$ \\
\hline $\begin{array}{l}\text { Technology } \\
\text { Partners' } \\
\text { Influence }\end{array}$ & $\begin{array}{l}\text { The influence of IT Consultant and IT } \\
\text { service provider for expert advice, IT } \\
\text { implementation, and training support in } \\
\text { the absence of internal IT expertise. } \\
\text { (Ghobakhloo et al. 2011) }\end{array}$ & $\begin{array}{l}\text { Environmental } \\
\text { Factors }\end{array}$ & $\begin{array}{l}\text { Shouk et al. 2012; Raymond, (2001); } \\
\text { Brown \& Kaewkitipong, 2009; Al-Qirim } \\
\text { (2007) and Thong (2001); Ghobakhloo } \\
(2011) \text {; }\end{array}$ \\
\hline $\begin{array}{l}\text { Firm } \\
\text { Strategic } \\
\text { Intent }\end{array}$ & $\begin{array}{l}\text { Firm Strategic Intent in terms of } \\
\text { competitive products, price, enhanced } \\
\text { information \& communication, expand } \\
\text { distribution, improve customer relations, } \\
\text { siege more resources, increase } \\
\text { economies of scale, enforce customer } \\
\text { relationship management, and strengthen } \\
\text { customer loyalty. (modified from Huang } \\
2006 \text { \& Raymond 2001) }\end{array}$ & $\begin{array}{l}\text { Organizational } \\
\text { Factors }\end{array}$ & $\begin{array}{l}\text { Huang (2006); Raymond, 2001; Brown \& } \\
\text { Kaewkitipong, 2009; Sila, (2015). }\end{array}$ \\
\hline
\end{tabular}




\begin{tabular}{|l|l|l|l|}
\hline $\begin{array}{l}\text { Perceived } \\
\text { Facilitators }\end{array}$ & \multicolumn{1}{|c|}{ Operational Definition (Source) } & \multicolumn{1}{|c|}{$\begin{array}{l}\text { Type of } \\
\text { Factors }\end{array}$} & \multicolumn{1}{|c|}{ Relevant Literature } \\
\hline $\begin{array}{l}\text { Compatible } \\
\text { Organisationa } \\
\text { 1 Culture }\end{array}$ & $\begin{array}{l}\text { Compatible Organisational Culture is the } \\
\text { bilateral familiarity in values, } \\
\text { perceptions, beliefs, principles, and } \\
\text { practices related to general business } \\
\text { conduct. (Modified from Huang 2006; } \\
\text { Karnali and Kurnia 2011) }\end{array}$ & $\begin{array}{l}\text { Organizational } \\
\text { Factors }\end{array}$ & $\begin{array}{l}\text { Huang (2006); Stafford (1994); Karnali } \\
\text { and Kurnia, 2011; Hofstede, 1984; } \\
\text { Hofstede, 1997 }\end{array}$ \\
\hline $\begin{array}{l}\text { Owner- } \\
\text { Manager } \\
\text { Support }\end{array}$ & $\begin{array}{l}\text { The owner's and manager's } \\
\text { involvement, motivation, perception, } \\
\text { attitude, and values in the adoption of } \\
\text { new technology or innovation. (modified } \\
\text { from Huang 2006) }\end{array}$ & $\begin{array}{l}\text { Individual } \\
\text { (Managerial) }\end{array}$ & $\begin{array}{l}\text { Factors } \\
\text { Brown \& Kaewkitipong, 2009; Al-Qirim } \\
\text { (2007) }\end{array}$ \\
\hline $\begin{array}{l}\text { Owner- } \\
\text { Manager } \\
\text { Education }\end{array}$ & $\begin{array}{l}\text { The owner's and manager‘s education is } \\
\text { a reflection of its ability and knowledge } \\
\text { to assimilate the benefits of IT } \\
\text { implementation. (Modified from } \\
\text { Raymond, 2001) }\end{array}$ & $\begin{array}{l}\text { Individual } \\
\text { (Managerial) } \\
\text { Factors }\end{array}$ & Raymond, (2001); Ghobakhloo (2011); \\
\hline $\begin{array}{l}\text { Owner- } \\
\text { Manager } \\
\text { Experience }\end{array}$ & $\begin{array}{l}\text { The owner's and manager's experience } \\
\text { in managing the travel services business } \\
\text { will impact the perceived benefits/values } \\
\text { of IT processes and systems. } \\
\text { (Modified from Raymond, 2001) }\end{array}$ & $\begin{array}{l}\text { Individual } \\
\text { (Managerial) } \\
\text { Factors }\end{array}$ & Raymond, (2001); Gorla et al. (2017) \\
\hline
\end{tabular}

Table 5 Barriers \& Facilitators of B2B Degree of Digital Use in Travel Services

\begin{tabular}{|c|c|c|c|}
\hline \multicolumn{2}{|r|}{ Type of Factors } & Barriers & Facilitators \\
\hline \multirow{3}{*}{$\begin{array}{l}\text { External } \\
\text { Factors }\end{array}$} & Technological Factors & $\begin{array}{l}\text { - IT Infrastructure Problems } \\
\text { - Perceived Security Risk } \\
\text { - High Technology Cost } \\
\text { - Perceived Complexity }\end{array}$ & $\begin{array}{l}\text { - Perceived Relative Advantage } \\
\text { - Perceived Compatibility }\end{array}$ \\
\hline & Environmental Factors & $\begin{array}{l}\text { - Lack of Critical Mass } \\
\text { - Legal and Regulatory } \\
\text { Issues }\end{array}$ & $\begin{array}{l}\text { - Supplier Pressure } \\
\text { - Customer Pressure } \\
\text { - Industry Pressure } \\
\text { - Environment Uncertainty } \\
\text { - Technology Partner Influence }\end{array}$ \\
\hline & $\begin{array}{l}\text { Inter-Organizational } \\
\text { Factors }\end{array}$ & - Lack of Supplier Trust & - B2B Relationship Intensity \\
\hline \multirow{2}{*}{$\begin{array}{l}\text { Internal } \\
\text { Factors }\end{array}$} & Organizational Factors & $\begin{array}{l}\text { - Organizational IT } \\
\text { Weakness }\end{array}$ & $\begin{array}{l}\text { - Firm Strategic Intent } \\
\text { - Compatible Organisational Culture }\end{array}$ \\
\hline & $\begin{array}{l}\text { Individual (Managerial) } \\
\text { Factors }\end{array}$ & & $\begin{array}{l}\text { - Owner-Manager Education } \\
\text { - Owner-Manager Experience } \\
\text { - Owner-Manager Support }\end{array}$ \\
\hline
\end{tabular}

Multiple theories lend support to the antecedent factors in the proposed conceptual model. Diffusion of innovation (DOI) theory (Roger 1983) is a process-based theory of digital adoption and usage that states that a combination of individual characteristics, innovation characteristics, and contextual characteristics influence the innovativeness of an organization, i.e., the adoption of intra-organizational 
systems. Rogers (1995) provides a detailed explanation of the diffusion of innovation processes among individuals as well as among organizations. The theory explained five determinant factors, relative advantage, compatibility, complexity, trialability, and observability, which influence the rate of technology adoption (Roger, 2003). The review for B2B travel services identifies perceived relative advantage and perceived compatibility as facilitators and perceived complexity as a barrier. The empirical paper review did not identify other factors, such as perceived trialability and perceived observability, as facilitators or barriers in B2B travel services. However, these other factors have been identified as determinant factors in another B2B context. Moreover, we can interpret that perceived complexity, and perceived observability are determinant factors that are relevant for the adoption stage and not for the usage stage.

Organizations are under pressure to be isomorphic with their environment (Burt 1987). Institutional Theory (IT) (DiMaggio and Power, 1983) asserts that the institutional environment influences the development of formal structures in any organization, often more profoundly than market pressures. DiMaggio and Power (1983) identified factors that influence the adoption of inter-organizational systems (IOSs). The three general mechanisms of isomorphism are coercive, mimetic, and normative pressures. Coercive (supplier) pressure, mimetic (customer) pressure, and normative (industry) pressures impact B2B digital usage.

Iacovou et al.'s (1995) model explains the inter-organizational system (IOS) characteristics that influence IT adoption and usage. It identifies three sets of factors - perceived benefits or issues, organizational readiness or weaknesses, and external pressure. The model explains that the determinant factors such as the IT infrastructure problem, perceived security risk, high technology cost, legal and regulatory issues, organizational IT weaknesses, organizational strategic intent, technology partner influence, lack of critical mass, and environmental uncertainty identified in the literature impact B2B digital usage, either positively or negatively, depending on the context of the investigation.

Agency theory (AT) (Eisenhardt 1989) explains that supplier organizations (principal) are in need of aligning the behaviors or outcomes of retail travel agencies (agents) to their expectations. The theory suggests that contracts based on incentives manage inter-organizational relationships. In our study, we find that interorganizational factors are identified in the retail travel agency literature in the context of B2B relationships. A retail travel agency digital usage study in Spain identifies the inter-organizational factor of B2B relationship intensity (Bigne et al., 2008) and lack of supplier trust in SME tourism agents study in developing countries of Nepal (Lama et al., 2020). The study of B2B e-commerce adoption for SMEs suggested a similar inter-organizational factor, supplier trust (Sila, 2013). Digital usage, unlike digital adoption, is considered an innovation of a continuous nature that can foster if there is a long-term orientation to the B2B relationship between buyer and supplier (Bigne et al., 2008).

Cultural compatibility is fundamental to the continuity of buyer-supplier relationships (Beugelsdijk et al., 2009). National culture theory (NCT) (Hofstede 1984) has stated that six dimensions can predict the behavior of individuals in society in specific situations. (1) Individualism (versus collectivism) is the extent to which people feel independent, as opposed to being interdependent as members of 
larger wholes. (2) Power distance refers to a situation where the less powerful members of organizations or institutions (such as the family) accept and expect an unequal distribution of power. (3) Masculinity (versus femininity) is the extent to which the use of force is endorsed socially. (4) Uncertainty avoidance explains a society's tolerance for uncertainty and ambiguity. (5) Long-term orientation (versus short-term orientation) deals with change. (6) Indulgence (versus restraint) deals with the acceptance of good things in life.

Hofstede subsequently extended the theory of society to a specific case of organizations. He defined organizational culture as six independent dimensions of practices: process-oriented versus result-oriented, job-oriented versus employeeoriented, professional versus parochial, open systems versus closed systems, tightly controlled versus loosely controlled, and pragmatic versus normative (Hofstede, 1997, Hofstede, 2011). Therefore, we can extend the theory to explain the situation of the relationship between retail travel agencies and online travel suppliers. A lack of compatible organizational culture will act as a deterrent for retail travel agencies, who are dependent on supplier organizations for IT implementation and technical support for digital adoption and usage. Retail travel agency owner-managers with experience (CEO experience, Thong \& Yap 1995) and education (CEO knowledge, Thong \& Yap 1995) regarding digital technologies perceive higher uncertainty and ambiguity in offline transactions compared to online purchases (Raymond, 2001). In these circumstances, owner-manager support (top management support, Thong \& Yap 1995) will facilitate digital usage (Huang 2006; Ghobakhloo \& Tang, 2013).

\subsection{Outcome: Degree of Digital Use}

Retail travel agencies are intermediaries that extend the travel- and tourism-related services of tour operators and direct suppliers. In the process, the suppliers decide a portion of their revenue as commission for these agencies. Retail travel agencies cater to the needs of a variety of customers, both corporate and individual travelers, for business and leisure. Most travel agencies provide integrated and customized online and offline services. Travel agencies classify their services into six categories: flight bookings, hotel bookings, tour packages, rail bookings, car rental services, and bus bookings.

The study revealed that all retail travel agencies have an online presence; the majority of the agencies have websites. The online study showed that the digital usage of all the sampled retail travel agencies is largely confined to lower levels of digital communication (e-mail, static website information, online directory, catalog sites, social media pages, and e-brochures). Websites did not have higher-order functions for digital transactions such as e-payments and e-booking,

The literature has defined digital usage as usage scope, or the extent of digital use for many different activities in the value chain such as supplier interface, customer interface, internal operations, sales and marketing, and customer service (Gibbs and Kraemer, 2004); usage intensity, or the extent of digital use as a percentage of total use for different activities in the value chain (Zhu and Kraemer, 2005); and digital usage, or the extent of the digital use of the number of digital applications (Grandon and Pearson, 2004; Molla and Licker, 2005b; Ghobakhloo et al., 2011).

For this study, we modified the following widely used definitions of digital usage to develop our research framework. 
The degree of digital use in organizations defines the extent of the use of digital processes to conduct value chain activities. The degree of digital use measures the breadth of use and the depth of use for each value chain activity that is on the Internet platform (Modified from Hart and Saunders 1998; Fichman 2000).

Exceptionally few studies have conceptualized digital usage as a process-based approach in the B2B travel services supply chain (Andreu et al., 2010; Bigne et al., 2008). The process-based method conceptualized digital usage in the supplierintermediary interface as a two-dimensional construct. The study conceptualizes two dimensions of $\mathrm{B} 2 \mathrm{~B}$ travel services as lower-order digital use-supplier digital communications - and higher-order digital use-supplier digital transactions (Andreu et al., 2010; Bigne et al., 2008). The study conceptualizes digital usage as the degree of digital use. The degree of digital use of retail travel agencies is the extent of their use of digital processes, and that of travel systems of suppliers is the extent to which their travel services need. Moreover, the width of use is measured as two dimensions: digital supplier communication and digital supplier transaction. The depth of use was measured as the share of digital communication to total supplier communication and the share of the digital transaction to total supplier transactions (Ghosh \& Dash, 2020).

Thus, we conceptualized the research propositions as follows:

P1 (a-m): Perceived Facilitators (a), Perceived Relative Advantage (b), Perceived Compatibility (c), Supplier Pressure (d), Customer Pressure (e), Industry Pressure (f), Environment Uncertainty (g), Technology Partner Influence (h), B2B Relationship Intensity (i), Firm Strategic Intent (j), Compatible Corporate Culture (k), Owner-Manager Education (l), and Owner-Manager Experience (m). Ownermanager support has a positive influence on the degree of digital use of the retail travel agency.

P2 (a-h): Perceived Barriers (a),IT Infrastructure Problem (b), Perceived Security Risk (c), High Technology Cost (d), Perceived Complexity (e), Lack of Critical Mass (f), Legal and Regulatory Issues (g), and Organizational IT Weaknesses (h). Lack of supplier trust has a negative influence on the degree of digital use of the retail travel agency.

\subsection{Moderating effects of Buyer Firm Size}

According to the resource-based view (RBV) (Barney 1991), organizational size is a reflection of the IT capability and slack resources of the organization (Zhu and Kraemer, 2005; Tornatzky and Fleischer, 1990). Therefore, organizational size is a determinant factor influencing digital usage. Past studies have treated organizational size as an organizational factor (internal factor).

Large organizations will have a surplus of resources, skilled employees, and experience that enable them to manage uncertainty and risk easily compared to relatively smaller organizations (MSMEs) (Levenburg et al., 2006; Yap, 1990; Sila, 2013).The ability of an organization to manage uncertainty and risk will depend on its capabilities and resources, i.e., organizational size. Organizational size is one of the best predictors of digital adoption and usage (Jeyaraj et al., 2006). Studies have empirically proven that buyer firm size as a control factor, a facilitator, a barrier, and a moderator in a different B2B context (Table 6). 
Firm size has been tested as a moderating factor in SMEs in developing countries (Sila 2013). The interactional effect of firm size with other determinant factors is untested in the travel services context. Firm size as a moderator in the B2B travel services context is untested in both developing and developed countries. Most of the studies have considered MSMEs as a homogeneous segment, and the impact due to variations in size within the sector needs attention(Brown \& Kaewkitipong, 2009). Thus, we can argue that larger SMEs are more likely to conduct digital usage compared to smaller SMEs. Therefore, the moderating effect of firm size needs investigation in B2B travel services in the context of the relationship between retail travel agencies and online travel suppliers.

Table 6 Literature Review of Effects of Firm Size on B2B Digital Usages

\begin{tabular}{|l|l|l|l|l|}
\hline $\begin{array}{c}\text { Determinant } \\
\text { Factors }\end{array}$ & Effects & Type of Factors & \multicolumn{1}{|c|}{ Context } & \multicolumn{1}{c|}{$\begin{array}{c}\text { Relevant } \\
\text { Literature }\end{array}$} \\
\hline Business Size & Facilitators & $\begin{array}{l}\text { Organizational } \\
\text { Factors }\end{array}$ & $\begin{array}{l}\text { SME, products \& } \\
\text { services, Iran }\end{array}$ & $\begin{array}{l}\text { Ghobakhloo et al., } \\
\text { 2011 }\end{array}$ \\
\hline Firm Size & Control & $\begin{array}{l}\text { Organizational } \\
\text { Factors }\end{array}$ & $\begin{array}{l}\text { Travel agency, services, } \\
\text { Spain }\end{array}$ & Bigne et al., 2008 \\
\hline Firm Size & Facilitators & $\begin{array}{l}\text { Organizational } \\
\text { Factors }\end{array}$ & $\begin{array}{l}\text { SME, products \& } \\
\text { services, England }\end{array}$ & $\begin{array}{l}\text { Ramdani et al., } \\
\text { 2013 }\end{array}$ \\
\hline Firm Size & Control & $\begin{array}{l}\text { Organizational } \\
\text { Factors }\end{array}$ & $\begin{array}{l}\text { Small Business Units, } \\
\text { Products, US }\end{array}$ & Wu et al., 2003 \\
\hline Firm Size & Moderator & $\begin{array}{l}\text { Organizational } \\
\text { Factors }\end{array}$ & $\begin{array}{l}\text { SME, services, } \\
\text { Developing countries }\end{array}$ & Sila, 2013 \\
\hline Firm Size & Barriers & $\begin{array}{l}\text { Organizational } \\
\text { Factors }\end{array}$ & $\begin{array}{l}\text { SME, Products \& } \\
\text { Services, Developed \& } \\
\text { Developing countries }\end{array}$ & $\begin{array}{l}\text { Zhu and Kraemer } \\
\text { 2005 }\end{array}$ \\
\hline Firm Size & Facilitators & $\begin{array}{l}\text { Organizational } \\
\text { Factors }\end{array}$ & $\begin{array}{l}\text { SME, products \& } \\
\text { services, Indonesia }\end{array}$ & $\begin{array}{l}\text { Rahayu \& Day, } \\
\text { 2015 }\end{array}$ \\
\hline Firm Size & Control & $\begin{array}{l}\text { Organizational } \\
\text { Factors }\end{array}$ & $\begin{array}{l}\text { Small Business Units, } \\
\text { Products, US }\end{array}$ & Wu et al., 2007 \\
\hline Firm Size & Facilitators & $\begin{array}{l}\text { Organizational } \\
\text { Factors }\end{array}$ & $\begin{array}{l}\text { Travel agency, services, } \\
\text { Thailand }\end{array}$ & $\begin{array}{l}\text { Brown \& } \\
\text { Kaewkitipong, } \\
\text { 2009 }\end{array}$ \\
\hline
\end{tabular}

Past studies have defined firm size in different ways. This study conceptualizes the firm size of retail travel agencies in three different ways to test for the propositions: one as per the Indian classification (investments in equipment) and the other as per international classification (number of employees). The three classifications are as follows:

Firm Size 1: defined as investments in equipment: (Government guidelines in India for service sector MSME, 2006)

- Less than 10 Lacs (microenterprise)

- 10 Lacs to less than 2 Crores (small enterprise) 
- 2 Crores to less than 5 Crores (medium-sized enterprise)

Firm Size 2: defined as number of employees: (SME Travel Agency study by Brown \& Kaewkitipong, 2009)

- 1-10 employees (microenterprise)

- 11-50 employees (small enterprise)

- 51-250 employees (medium enterprise)

Firm Size 3: defined as number of employees: (SME study by Zhu and Kraemer 2005)

- 1-50 employees (microenterprise)

- 51-100 employees (small enterprise)

- 101-250 employees (medium enterprise)

For the study, micro enterprises and small enterprises are considered in the category small SME firm (small retail travel agency), and medium enterprises form the large SME firm category (large retail travel agency).Therefore, we conceptualized the research propositions for contingency factor buyer firm size as P3 (a): When firm size is large, the positive effect of perceived facilitators on the degree of digital use of the retail travel agency strengthens.

P3 (b): When firm size is large, the negative effect of the perceived barriers on the degree of digital use of the retail travel agency weakens.

P3 (c): When firm size is small, the positive effect of the perceived facilitators on the degree of digital use of the retail travel agency weakens.

P3 (d): When firm size is small, the negative effect of the perceived barriers on the degree of digital use of the retail travel agency strengthens.

\subsection{Conceptual Model}

The study integrated literature and theories from the diverse domains of information technology, consumer behavior, B2B marketing, and relationship marketing to develop an integrated B2B digital usage framework (Figure 2).

\subsection{Theoretical Contributions}

\section{Conclusions}

The study makes a number of contributions to the literature on business-to-business marketing strategy, digital strategy, supply chain, and information technology. The conceptual study resulted in the categorization of determinant factors into barriers and facilitators of the degree of digital use in B2B travel services, particularly from the perspective of retail travel agencies and online travel suppliers. Studies on supply chains for digital usage in the B2B context have taken the supplier perspective, customer perspective, or dyadic perspective, but supply-chain reviews from intermediary perspectives are minimal. The paper attempted to address this lessexplored domain, particularly the service supply chain for intermediaries. The study combines literature and theories from diverse domains, such as information technology, consumer behavior, B2B marketing, organizational behavior, and relationship marketing, to develop an integrated B2B digital usage framework. The 


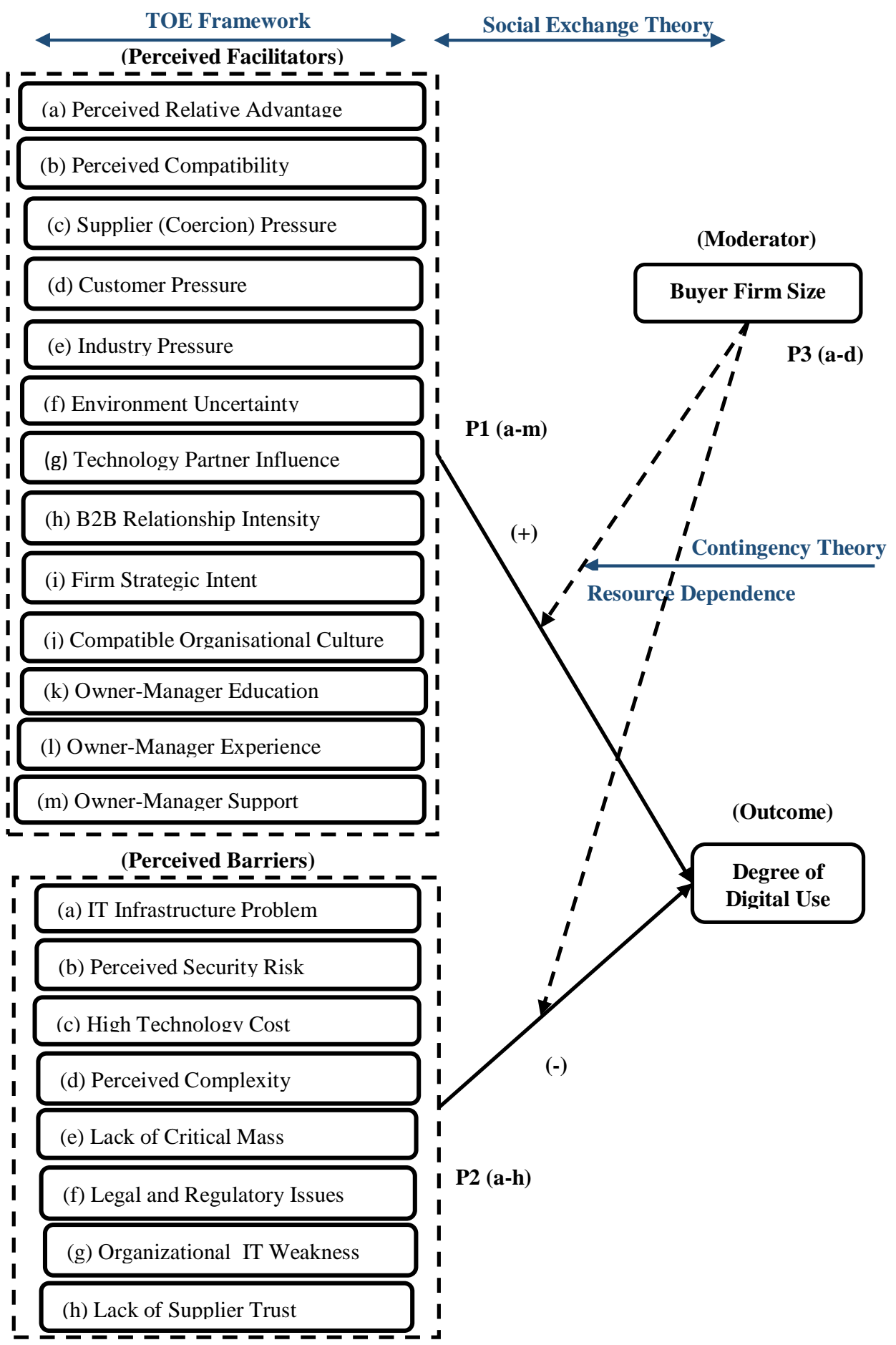

Figure 2: Proposed Conceptual Model. Theoretical Support and Research Propositions 
study identifies barriers and facilitators for B2B digital usage distinct from earlier studies on digital adoption. Although the study of barriers and facilitators for digital adoption and usage has been acknowledged as having strategic significance in the B2B supply chain, such studies are mostly on digital adoption and limitedlyconsiderB2B digital usage. Furthermore, studies on the service supply chain, particularly the travel service supply chain, are minimal. The extant studies are mostly concentrated in developed countries, with few in developing counties and none in the Indian context. This study contributes to this missing link in the supplychain literature and draws the attention of scholars to this neglected yet critical research domain. Most studies conceptualized the direct effects of buyer firm size on digital adoption and usage. The study emphasizes that firm size is a contingency variable and conceptualizes the interactional effects of buyer firm size on the influence of barriers and facilitators on the degree of digital use. The study also made a unique contribution to process-based conceptualization as the width and depth of digital use for the degree of digital use in the supplier interface value chain in the B2B travel services context.

\subsection{Managerial Contributions}

The study also has significant implications for practitioners and policymakers in these fields, who will be able to identify the key barriers and facilitators that impact digital usage, distinct from digital adoption, particularly in the relationship between travel intermediaries and online travel suppliers. Most large organizations considered factors per the TOE framework. Nevertheless, the study points to the inclusion of contextual variables such as individual (managerial) factors that directly affect B2B digital usage in micro, small, and medium-sized organizations (MSMEs), where owner-managers have a significant influence on decisions. Owner-managers can focus on self-development methods to improve individual factors such as digital experience, education (knowledge), and management support, which directly impact B2B digital usage. The study also points to the inclusion of contextual variables of inter-organizational factors. The study highlights the fact that inter-organizational factors such as supplier trust and B2B relationship intensity, considered important contextual variables in a buyer-supplier relationship in an offline context, are also important for digital relationships. The study will help online travel suppliers and travel intermediaries work out strategies to strengthen buyer-supplier relationships. Retail travel agencies who are under threat of disintermediation in the industry as travel suppliers are directly targeting consumers who can work out re-intermediation strategies. The study will also help MSME owner-managers understand all the factor categories and their classification as barriers and facilitators and help develop B2B digital strategies.

\subsection{Limitations and Future Research Directions}

The study is theoretical and conceptual. A subsequent descriptive survey will lead to conclusive outcomes. The study was conceptualized for MSME travel agencies and did not include the perspective of large travel agencies. Therefore, the barriers and facilitators identified may be specific to MSME travel agencies and may not apply to all types of travel agencies. Researchers can use the conceptual study for other B2B travel service contexts, such as the relationship between retail travel agencies and 
direct travel service providers with specific travel category focuses, such as air travel ticketing, hotel booking, tour booking, rail ticketing, or car rental booking. Future studies can include more firm characteristics as moderating variables, such as travel product importance, travel product experience, and type of business, to improve their generalizability. The conceptual research of B2B travel services can be extended to a meta-analysis as barriers and facilitators of B2B digital usages in different services and product contexts to generate a comprehensive list of B2B digital usage barriers and facilitators. The current study focused on the antecedent factors of the degree of digital use. The buyer experience of digital usage in the supply chain will drive repeat and continuous usage based on the evaluation of performance. The study can be extended to include both antecedents (drivers) and consequences (outcomes) together in the same context, particularly the context of the service, which is also an under-researched area in the digital supply-chain domain.

\section{References}

1. Al-Qirim, N. (2007). The adoption of eCommerce communications and applications technologies in small businesses in New Zealand. Electronic Commerce Research and Applications, 6(4), pp. 462-73.

2. Andreu, L., Aldas, J., Bigne, J. E. \& Mattila, A.S. (2010). An analysis of ebusiness adoption and its impact on relational quality in a travel agency-supplier relationships. Tourism Management, 31, pp. 777-787.

3. Barney, J. (1991). Firm Resources and Sustained Competitive Advantage. Journal of Management, 17(1), pp. 99-120.

4. Beugelsdijk, S., Koen, C. \&Noorderhaven, N. (2009). A dyadic approach to the impact of differences in organizational culture on relationship performance. Industrial Marketing Management, 38, pp. 312-323.

5. Bigne, J. E., Aldas, J., \& Andreu, L. (2008). B2B Services: IT Adoption in travel agency supply chains. Journal of Services Marketing, 22(6), pp. 454-464.

6. Blanton, J. E., Watson, H. J. \& Moody, J. (1992). Toward a Better Understanding of Information Technology Organization: A Comparative Case Study. MIS Quarterly, 16(4), pp. 531

7. Blau, P. M. (1964). Social Exchange Theory. Retrieved September 3, 2007.

8. Brown, D. \& Kaewkitipong, L. (2009). Relative size and complexity: e-business use in small and medium-sized tourism enterprises in Thailand. Journal of Enterprise Information Management, 22(1-2), pp. 212-231.

9. Buhalis, D. \& Licata, M. C. (2002). The future of eTourism intermediaries. Tourism Management, 23, pp. 207-220.

10. Burt, R. S. (1987). Social Contagion and Innovation: Cohesion Versus Structural Equivalence. American Journal of Sociology, 92(6), pp. 1287-1335.

11. Chircu, A. M. \& Kauffman, R.J. (2000). Reintermediation Strategies in Business-to-Business Electronic Commerce. International Journal of Electronic Commerce, 4(4), pp. 7-42.

12. DiMaggio, P., \& Powell, W. W. (1983). The iron cage revisited: institutional isomorphism and collective rationality in organizational fields. American Sociological Review, 48(2), pp. 147-160.

13. Eisenhardt, K. M. (1989). Agency Theory: An Assessment and Review. Academy of Management Review, 14(1), pp. 57-74. 
14. Emerson, R. M. (1976). Social Exchange Theory. Annual Review of Sociology, 2, pp. 335-362.

15. Fichman, R. G. (2000). The diffusion and assimilation of information technology innovations. R. Zmud, ed. Framing the Domains of IT Management: Projecting the Future through the Past. Pinnaflex Publishing, Cincinnati, $\mathrm{OH}$.

16. Ghobakhloo, M., Aranda, D. A. \& Amado, J. B. (2011). Adoption of e-commerce applications in SMEs. Industrial Management \& Data Systems, 111(8), pp. 1238-1269.

17. Ghobakhloo, M. \& Tang, S.H. (2013). The role of owner/manager in adoption of electronic commerce in small businesses. Journal of Small Business and Enterprise Development, 20(4), pp. 754-787.

18. Ghosh, DP. \& Dash, S. (2020). Barriers and Facilitators of Degree of Digital Use: Moderating role of Firm Size. Proceedings in Seventeenth AIMS International Conference on Management (AIMS-17), AIMS International and Indian Institute of Management Kozhikode, Kerala, India, pp. 1601-1612.

19. Glaser, B.G. \& Strauss, A. L. (1967). Insight and Theory Development, in Discovery of Grounded Theory. Aldine Publishing Company, Chicago, pp. 251259.

20. Gorla, N., Chiravuri, A. \& Chinta, R.(2017). Business-to-business e-commerce adoption: An empirical investigation of business factors. Information Systems Frontiers, 19, pp. 645-667.

21. Grandon, E.E. \& Pearson, J.M. (2004). Perceptions of strategic value and adoption of e-commerce: a theoretical framework and empirical test, in Currie, W. (Ed.), Value Creation from E-business Models: Issues and Perspectives in Value Creation from E-business Models, Elsevier, Oxford.

22. Hart, P. J. \& Saunders, C. S. (1998). Emerging electronic partnerships: Antecedents and dimensions of EDI use from the supplier's perspective. Journal of Management Information Systems, 14(4), pp. 87-111.

23. Heung, V. (2003). Internet usage by international travelers: reasons and barriers. International Journal of Contemporary Hospitality Management, 15(7), pp. 370-378.

24. Huang, L. (2006). Building up a B2B e-commerce strategic alliance model under an uncertain environment for Taiwan's travel agencies. Tourism Management, 27 (6), pp.1308-1320.

25. Hofstede, G. (1983). Culture's Consequences: International Differences in Work-Related Values. Administrative Science Quarterly (Johnson Graduate School of Management, Cornell University), 28 (4), pp. 625-629.

26. Hofstede, G. (1993). Cultures and Organizations: Software of the Mind. Administrative Science Quarterly (Johnson Graduate School of Management, Cornell University), 38 (1), pp.132-134.

27. Hofstede, G. (1997). Cultures and Organisations: Software of the Mind. McGraw-Hill, USA.

28. Hofstede, G. (2011). Dimensionalizing Cultures: The Hofstede Model in Context. Online Readings in Psychology and Culture, International Association for Cross-Cultural Psychology and Scholar Works @ GVSU, 2(1).

29. Homans, G.C. (1958). Social Behavior as Exchange. American Journal of Sociology, 63(6), pp. 597-606. 
30. Iacovou, C.L., Benbasat, I. \& Dexter, A.S. (1995). Electronic data interchange and small organizations: Adoption and impact of technology. MIS Quarterly, 19(4), pp. 465-485.

31. Jackson, P. \& Harris, L. (2003). E-Business and organisational change: Reconciling traditional values with business transformation. Journal of Organizational Change Management, 16(5), pp. 497- 511.

32. Jahanshahi, A. A., \& Zhang, S. X. (2013). E-commerce for SMEs: empirical insights from three countries. Journal of Small Business and Enterprise Development, 20(4), pp.849-865.

33. Karnali, R. J. \& Kurnia, S. (2011). The Adoption of B2B e-Commerce Initiatives by The Indonesian Grocery Industry. Asia Pacific Conference on Information Systems (PACIS), Proceedings. 86.

34. Kaynak, E, Tatoglu, E. \& Kula, V. (2005). An analysis of the factors affecting the adoption of electronic commerce by SMEs. International Marketing Review, 22(6), pp. 623-640.

35. Kurnia, S., Karnali, R. J. \& Rahim, M. M. (2015). A qualitative study of business-to-business electronic commerce adoption within The Indonesian grocery industry. Information \& Management, 51, pp 518 -536.

36. King, W.R. \& Teo, T. S. H. (1994). Facilitators and inhibitors for the strategic use of information technology. Information \& Management, 27, pp. 71-87.

37. Lama, S., Pradhan, S. \& Shrestha, A. (2020). Exploration and implication of factors affecting e-tourism adoption in developing countries: a case of Nepal. Information Technology \& Tourism, DOI:10.1007/s40558-019-00163-0

38. Law, R., Leung, K. \& Wong, R. (2004). The impact of the Internet on travel agencies. International Journal of Contemporary Hospitality Management, 16(2), pp. 100-107.

39. Levenburg, N., Magal, S.R. \& Kosalge, P. (2006). An exploratory investigation of organizational factors and e-business motivations among SMFOEs in the US. Electronic Markets, 16(1), pp. 70-84.

40. Li, H. \& Suomi, R. (2008). Internet Adoption in Tourism Industry in China, International Federation for Information Processing (IFIP), Towards Sustainable Society on Ubiquitous Networks, eds. Oya, M., Uda, R., Yasunobu, C., (Boston: Springer), 286, pp.197 - 208.

41. Oliveira, T. and Martins, M.F. (2008). A comparison of web site adoption in small and large Portuguese firms. ICE-B 2008: Proceedings of the international conference on e-business. Porto, Portugal, July, pp. 370-377.

42. Martins, M. and Oliveira, T. (2009). Determinants of e-commerce adoption by small firms in Portugal. Proceedings of the 3rd European conference on information management and evaluation. Gothenburg, Sweden, September, pp. 328-338.

43. Oliveira, T. and Martins, M.F. (2009). Determinants of information technology adoption in Portugal. ICE-B 2008: Proceedings of the international conference on e-business, Milan. Italy, July, pp 264-270.

44. Oliveira, T. and Martins M.F. (2010b). Understanding e-business adoption across industries in European countries. Industrial Management \& Data System, 110 (9), pp. 1337-1354. 
45. Oliveira, T. \& Martins, M. F. (2011). Literature Review of Information Technology Adoption Models at Firm Level. Electronic Journal Information Systems Evaluation, 14(1), pp. 110-121.

46. Patterson, K.A., Grimm, C.M., \& Corsi, T.M. (2003). Adopting new technologies for supply chain management. Transportation Research Part E, 39, pp. 95-121.

47. Pfeffer, J. \& Salancik, G.R. (2003). The External Control of Organizations: A Resource Dependence Perspective. Stanford (Calif.): Stanford Business Books.

48. Rahayu, R. \& Day, J. (2015). Determinant Factors of E-Commerce Adoption by SMEs in Developing Country: Evidence from Indonesia. World Conference on Technology, Innovation and Entrepreneurship. Procedia - Social and Behavioural Sciences, 195 , pp. $142-150$.

49. Ramdani, B., Chevers, D. \& Williams, D. A. (2013). SMEs' adoption of enterprise applications: A technology-organization-environment model. Journal of Small Business and Enterprise Development, 20(4), pp.735-753.

50. Raymond, L. (2001). Determinants of Web site implementation in small businesses. Internet Research, 11(5), pp.411-424.

51. Rogers, E. M. (1983). Diffusion of Innovations. 3rd edition. The Free Press, New York.

52. Rogers, E. M. (1995). Diffusion of Innovations. 4th edition. The Free Press, New York.

53. Rogers, E. M. (2003). Diffusion of Innovations. 5th edition. The Free Press, New York.

54. Rossignoli, C. \& Ricciardi, F. (2015). Theories Explaining Inter-Organizational Relationships in Terms of Coordination and Control Needs, Chapter2. InterOrganizational Relationships: Towards a Dynamic Model for Understanding Business Network Performance, Springer, 8, pp. 7-36.

55. Shouk, M.A. \& Eraqi, M.I. (2015). Perceived barriers to e-commerce adoption in SMEs in developing countries: the case of travel agents in Egypt. International Journal of Services and Operations Management, 21(3), pp. 332353.

56. Shouk, M.A. \& Lim, W. (2012). Drivers of E-Commerce Adoption in Egyptian Travel Agents. Information and Communication Technologies in Tourism. Fuchs M. et al. (eds.), pp 143-154.

57. Shouk, M.A., Megicks, P. \& Lim, W. (2012). Internet Adoption by Travel Agents: a Case of Egypt. International Journal of Tourism Research, 15(3), pp. 298-312.

58. Sila, I. (2013). Factors affecting the adoption of B2B e-commerce. Electronic Commerce Research, 13, pp. 199-236.

59. Sila, I. (2015). The state of empirical research on the adoption and diffusion of business-to-businesse-commerce. International Journal of Electronic Business. 12 (3), pp.258-301.

60. Stafford, E. R. (1994). Using co-operative strategies to make alliance work. Long Range Planning, 27 (3), pp. 69-70.

61. Teo, H. H., Wei, K. K. \& Benbasat, I. (2003). Predicting Intention to Adopt Inter-organizational Linkages: An Institutional Perspective. MIS Quarterly, 27(1), pp. 19-49. 
62. Teo, T. S. H., Ranganathan, C., \& Dhaliwal, J. (2006). Key dimensions of inhibitors for the deployment of web-based business-to-business electronic commerce. IEEE Transactions on Engineering Management, 53(3), pp. 395411.

63. Thao, H. T. P. \& Swierczek, F.W. (2008).Internet use, customer relationships and loyalty in the Vietnamese travel industry. Asia Pacific Journal of Marketing and Logistics, 20(2), pp. 190-210.

64. Thong, J.Y.L. \& Yap, C.S. (1995). CEO characteristics, organizational characteristics, and information technology adoption in small business. Omega, 23(4), pp. 429-442.

65. Tornatzky, L. G. \& Fleischer, M. (1990). The Processes of Technological Innovation. Lexington Books, Lexington, MA.

66. Tornatzky, L. G., Fleischer, M. \& Chakrabarti, A. K. (1990). The processes of technological innovation. Lexington Books, Lexington, MA.

67. Tsai, H. T., Huang, L., \& Lin, C. G. (2005). Emerging e-commerce development model for Taiwanese travel agencies. Tourism Management, 26(5), pp. 787-796.

68. Tsaur, S. H., Yung, C. Y., \& Lin, J. H. (2009). The relational behavior between wholesaler and retailer travel agencies: evidence from Taiwan. Journal of Hospitality \& Tourism Research, 30(3), pp. 333-353.

69. Vatanasakdakul, S. \& D'Ambra, J. (2006).An exploratory study of the sociocultural impact on the adoption of e-commerce for firms in the tourism industry of Thailand. European Conference on Information Systems (ECIS), Proceedings. pp 1-13

70. Williamson, O. E. (1975). Markets and Hierarchies: Analysis and Antitrust Implications. Free Press, New York.

71. Williamson, O.E. (1981). The Economics of Organization: The Transaction Cost Approach. American Journal of Sociology, 87(3), pp. 548-577.

72. Wu, F. \& Lee, Y. K. (2005). Determinants of e-communication adoption: the internal push versus external pull factors. Marketing Theory, 5(1), pp. 7-31.

73. Wu, F., Mahajan, V. \& Balasubramanian, S. (2003). An analysis of e-business adoption and its impact on business performance. Journal of the Academy of Marketing Science, 31(4), pp. 425-447.

74. Wu, F., Zsidisin, G. A. \& Ross, A. D. (2007). Antecedents and outcomes of eprocurement adoption: an integrative model. IEEE Transactions on Engineering Management, 54(3), pp. 576-587.

75. Yap, C.S. (1990). Distinguishing characteristics of organizations using computers. Information and Management, 18(2), pp. 97-107.

76. Zhu, K., Kraemer, K.L. \& Xu, S. (2003). Electronic business adoption by European firms: A cross-country assessment of the facilitators and inhibitors. European Journal of Information Systems, 12(4), pp. 251-268.

77. Zhu, K. \& Kraemer, K. L. (2005). Post-Adoption Variations in Usage and Value of E-Business by Organizations: Cross-Country Evidence from the Retail Industry. Information Systems Research, 16(1), pp. 61-84.

78. Zhu, K., Kramer, K. L. \& Xu, S. (2006). The process of innovation assimilation by firms in different countries: A technology diffusion perspective on ebusiness. Management Science, 52(10), pp. 1557-1776. 


\section{About Our Authors}

Deviprasad Ghosh achieved a bachelor's degree in Electrical \& Electronics Engineering from Birla Institute of Technology, Mesra Ranchi, a master's degree in Management from S.P. Jain Institute of Management \& Research (SPJIMR), Mumbai (1996). Since 2016, he has been a Doctoral Scholar in Digital Marketing \&Strategy at Indian Institute of Management (IIM) Lucknow. He is a certified Project Management Professional (PMP) from the Project Management Institute, Pennsylvania, US (2012). He has 25 years of experience as a practitioner, trainer and consultant in project and product management. He is currently working as Assistant Professor at the Institute of Management Technology Hyderabad

Satyabhushan Dash achieved a Ph.D. from Vinod Gupta School of Management, Indian Institute of Technology (IIT), Kharagpur (2004). During his Ph.D., he was a Visiting Doctoral Research Fellow at I.H. Asper School of Business, University of Manitoba, Canada. He was awarded the Canadian Studies Doctoral Research Fellowship in Management (2001). He is currently working as Professor of Marketing and Chairperson, Centre for Marketing in Emerging Economies at Indian Institute of Management, Lucknow. He has coauthored the most extensive selling marketing research textbook, titled 'Marketing Research: An Applied Orientation,' with Prof. Naresh K. Malhotra. 